\title{
Introduction to the special issue on value capture for transportation finance
}

\author{
Zhirong Jerry Zhao \\ David Levinson \\ University of Minnesota ${ }^{\text {a }} \quad$ University of Minnesota $^{\text {b }}$
}

In recent years, shrinking state and local budgets, declining purchasing power of fuel tax revenues, and growing capital and maintenance costs have resulted in substantial shortfalls in transport funding. With the growing realization that the cost of transport will not be sufficiently met by the existing financing and revenue generation methods, new methods to aid or replace the present system have been studied, one of which is value capture.

The present US transport funding system emphasizes user fees. Value capture, on the other hand, aims to recover the value of benefits received by property owners or developers due to infrastructure improvements, and use these revenues to fund such improvements. The primary rationale of value capture is that the beneficiaries of transport investment are not limited to direct users (e.g. motorists, transit riders etc.) but also include landowners and developers who benefit from enhanced location advantages.

To understand value capture better, we propose a general framework of transport finance. Following the benefit principle that the cost of transportation for a contributor should be proportional to the benefits received, different instruments may be designed to match different categories of benefits and the different ways in which these benefits are measured. As Figure ?? shows, the beneficiaries can fall under three broad categories: the unrestricted general public; restricted non-user beneficiaries; and direct users of facilities.

In the broadest sense, transport improvements create benefits for the general public within the whole jurisdiction, because the enhanced infrastructure may lead to economic or social returns signified by the growth of the general tax base. Accordingly, transport may be given allocations from a government general fund that comes from all revenue sources. This is the case for many local governments in the United States and many other countries. Most directly, transport benefits are enjoyed by users, such as vehicle operators or transit passengers. This provides the rationale of dedicated special rev-

${ }^{a}$ Hubert H. Humphrey Institute of Public Affairs

b Dept. of Civil Engineering. dlevinson@umn.edu enues for transportation. For vehicle operators, the corresponding financial instruments would be gas taxes, distancebased (mileage) charges, vehicle sales taxes or vehicle property taxes, wheelage charges, or tolls, depending on how driving benefits are measured. Some options above, such as gas taxes or vehicle sales taxes, have been widely used by the US federal government and the states.

Between the general public and direct users, we can also define a restricted group of beneficiaries who are not direct users of facilities but who enjoy benefits because of their enhanced location advantages. As these property owners or developers benefit from transport value creation, they are the targeted contributors of value capture. Different ways to measure the value gains give rise to a range of different value capture policies, which may be categorized in two groups Iacono et al. (2009). Aiming to capture increased property values due to infrastructure improvements, the first group can include land value taxation (discussed in two papers in this issue), special assessment financing (Zhao and Larson 2011), tax increment financing (Zhao et al. 2010), transportation utility fees (also discussed herein); aiming to capture the value of enhanced development rights, the second group can include negotiated exactions (Altshuler et al. 1993; Been 2010), development impact fees (Jung et al. 2009; Mullen 2008), joint development (discussed in this volume), and air rights development (King et al. 2008).

This special issue includes 5 articles on several value capture strategies used in transportation finance.

"Joint development as a a transportation finance strategy" (Zhao, Das, and Larson) explores the experience in the US and Asia. Joint development has a number of advantages: linking costs to benefits while providing both public and private benefits. However it incurs large transaction costs, which is especially a factor where the infrastructure developer and land developer are separate agents.

"Rail integrated communities in Tokyo" (Calimente) contrasts RICs with Transit Oriented Developments (TODs). RICs are "high density, safe, mixed-use, pedestrian-friendly 


\begin{tabular}{|c|c|c|c|c|c|c|}
\hline \multirow{2}{*}{$\begin{array}{l}\text { Funding } \\
\text { Mechanism }\end{array}$} & \multirow[t]{2}{*}{ Beneficiaries } & & \multirow{2}{*}{$\begin{array}{l}\text { Measurement of } \\
\text { Benefit }\end{array}$} & \multirow{2}{*}{$\begin{array}{l}\text { Finance } \\
\text { Instrument }\end{array}$} & \multicolumn{2}{|c|}{ Cost Type } \\
\hline & & & & & Upfront & Ongoing \\
\hline $\begin{array}{l}\text { General } \\
\text { Revenue }\end{array}$ & General public & & General tax base growth & $\begin{array}{l}\text { General fund alloca- } \\
\text { tion; property tax; } \\
\text { transportation sales } \\
\text { tax }\end{array}$ & - & - \\
\hline \multirow[t]{8}{*}{$\begin{array}{l}\text { Value } \\
\text { Capture }\end{array}$} & $\begin{array}{l}\text { Restricted non- } \\
\text { user beneficiaries }\end{array}$ & Landowners & Land value growth & Land Value Taxes & - & $\bullet$ \\
\hline & & & Property tax growth & $\begin{array}{l}\text { Tax Increment } \\
\text { Financing }\end{array}$ & - & \\
\hline & & & Assessed special benefits & Special Assessment & - & \\
\hline & & & Transportation utility & $\begin{array}{l}\text { Transportation Utility } \\
\text { Fees }\end{array}$ & & - \\
\hline & & Developers & $\begin{array}{l}\text { Off-site development } \\
\text { opportunities }\end{array}$ & $\begin{array}{l}\text { Development Impact } \\
\text { Fees }\end{array}$ & $\bullet$ & \\
\hline & & & Off-site access benefits & Negotiated Exactions & $\bullet$ & $\bullet$ \\
\hline & & & Development privileges & Joint Development & - & $\bullet$ \\
\hline & & & $\begin{array}{l}\text { On-site development } \\
\text { opportunities }\end{array}$ & Air Rights & - & $\bullet$ \\
\hline \multirow[t]{6}{*}{ User Fees } & $\begin{array}{l}\text { Users of } \\
\text { transportation } \\
\text { facilities }\end{array}$ & $\begin{array}{l}\text { Vehicle } \\
\text { operators }\end{array}$ & $\begin{array}{l}\text { Gas consumption } \\
\text { Mileage }\end{array}$ & $\begin{array}{l}\text { Gas taxes } \\
\text { Mileage-based } \\
\text { charges }\end{array}$ & - & • \\
\hline & & & Vehicle units/types & $\begin{array}{l}\text { Vehicle sales tax; } \\
\text { license tab fee; } \\
\text { wheelage charges }\end{array}$ & - & • \\
\hline & & & General access rights & Tolling & & • \\
\hline & & & $\begin{array}{l}\text { Demand-controlled } \\
\text { access rights }\end{array}$ & Congestion pricing & & $\bullet$ \\
\hline & & & $\begin{array}{l}\text { Rights to incur environ- } \\
\text { mental impacts }\end{array}$ & $\begin{array}{l}\text { Transportation envi- } \\
\text { ronmental taxes/fees }\end{array}$ & & • \\
\hline & & Passengers & Ridership & Fare or permits & & $\bullet$ \\
\hline
\end{tabular}

Figure 1: Value capture in the general framework of transportation finance.

developments around railway stations that act as community hubs, served by frequent, all-day, rail rapid transit and are accessed primarily on foot, by bicycle, or by public transit." These have been created by the private Japanese railways, who internally capture the synergies between transport infrastructure creating land value, and high land densities producing rail riders.

"Prospects for transportation utility fees" (Junge and Levinson) examines the economic efficiency and equity effects of this emerging form of local transportation funding. In the United States, the majority of funds for local streets and roads comes from property taxes. The basis of property value is not proportional to the benefits users receive from local streets and roads. A transportation utility fee would be proportional to the expected use of the roadways, typically proportional the expected trips generated from the site rather than its monetary value. This is particularly important for commercial properties. Practical considerations remain, and while no system is perfectly proportional to use, TUFs improve upon existing practice.

"Financing transportation with land value taxes: Effects on development intensity" (Junge and Levinson) considers the hypothetical effects of a land value tax in three Minnesota cities: Minneapolis, Richfield, and Bloomington. Using a split-rate tax, as the ratio of land value: property value increases, the model predicts higher development intensities.

"The value capture potential of the Lisbon subway" (Martínez and Viegas) aims to estimate the possible revenue from value capture that could be used to finance the Lisbon subway. A simulation model is used to estimate changes in land development, and then a hedonic model estimates property value. Lisbon has a land value tax, so the amount of additional revenue is computed. Alternatively a special assessment could be employed. These additional funds can justify expansion of the subway. 


\section{References}

Altshuler, A. A., J. A. Gómez-Ibáñez, and A. M. Howitt. 1993. Regulation for revenue: The political economy of land use exactions. Brookings Institution Press.

Been, V. 2010. Community benefits agreements: A new local government tool or another variation on the exactions theme? University of Chicago Law Review, pp. 5-35.

Calimente, J. 2012. Rail integrated communities in Tokyo. Journal of Transport and Land Use, 5(1):19-32. doi: 10.5198/jtlu.v5i1.280.

Iacono, M., D. Levinson, Z. Zhao, , and A. Lari. 2009. Value capture for transportation finance. Technical Research Report CTS 09-18, University of Minnesota: Center for Transportation Studies.

Jung, C., C. Y. Roh, and Y. Kang. 2009. Longitudinal effects of impact fees and special assessments on the level of capital spending, taxes, and long-term debt in American cities. Public Finance Review, 37(5):613.

Junge, J. and D. Levinson. 2012a. Economic and equity effects of transportation utility fees. Journal of Transport and Land Use, 5(1):33-47. doi: 10.5198/jtlu.v5i1.141.

Junge, J. and D. Levinson. 2012b. Financing transportation with land value taxes: Effects on development intensity. Journal of Transport and Land Use, 5(1):49-63. doi: 10.5198/jtlu.v5i1.148.

King, D., K. J. Krizek, and D. Levinson. 2008. Designing and assessing a teaching laboratory for an integrated land use and transportation course. Transportation Research Record, 2046(1):85-93.

Martínez, L. M. and J. M. Viegas. 2012. The value capture potential of the Lisbon subway. Journal of Transport and Land Use, 5(1):65-82. doi: 10.5198/jtlu.v5i1.251.

Mullen, C. 2008. National impact fee survey: 2008. Austin, Texas: Duncan Associates. http://www.impactfees.com/ publications\%20pdf/2008_survey.pdf.

Zhao, Z., K. V. Das, and K. Larson. 2012. Joint development as a value capture strategy in transportation finance. Journal of Transport and Land Use, 5(1):5-17. doi: 10.5198/jtlu.v5i1.142.

Zhao, Z. J., K. V. Das, and K. Larson. 2010. Tax increment financing as a value capture strategy in funding transportation. Transportation Research Record, 2187(-1):1-7.

Zhao, Z. J. and K. Larson. 2011. Special assessments as a value capture strategy for public transit finance. Public Works Management \& Policy, 16(4):320-340. 